Specifically, we recommend replacing "STEM" with "worthwhile" or "meaningful," and focusing on the value of careers and such factors as personvocation, person-organization, and person-job fit for individuals without mention of age, race, or gender. Although it is true that fewer women choose STEM careers, the careers those women ultimately do choose are still impactful and meaningful and thus should be equally valued not only in accordance with the idea of compensable factors, but in society in general. Indeed, all of the issues raised by the focal article authors-biases, discrimination, and so on-go far beyond STEM.

\title{
References
}

Busso, M. (2017). Women close gender pay gap in two STEM jobs, lag in others. https://www.bloomberg. com/graphics/2017-women-stem-jobs/

Cheryan, S., Ziegler, S. A., Montoya, A. K., \& Jiang, L. (2017). Why are some STEM fields more gender balanced than others? Psychological Bulletin, 143, 1-35. doi:10.1037/bul0000052

Levanon, A., England, P., \& Allison, P. (2009). Occupational feminization and pay: Assessing causal dynamics using 1950-2000 U.S. census data. Social Forces, 88, 865-891.

Miner, K. N., Walker, J. M., Bergman, M. E., Jean, V. A., Carter-Sowell, A., January, S. C., \& Kaunas, C. (2018). From "her" problem to "our" problem: Using an individual lens versus a social-structural lens to understand gender inequity in STEM. Industrial and Organizational Psychology: Perspectives on Science and Practice, 11(2), 267-290.

National Science Foundation. (2014). Integrated postsecondary education data system, 2013, completions survey. National Center for Science and Engineering Statistics: Integrated Science and Engineering Resources Data System (WebCASPAR). Retrieved from https://webcaspar.nsf.gov

Ranji, U., \& Salganicoff, A. (2014). Balancing on shaky ground: Women, work and family health. https://www.kff.org/womens-health-policy/issue-brief/data-note-balancing-on-shakyground-women-work-and-family-health/

Williams, C. (1992). The glass escalator: Hidden advantages for men in "female" professions. Social Problems, 39, 253-267.

\section{Issues of Gender Inequity Go Beyond STEM}

\author{
P. D. Harms and Karen Landay \\ University of Alabama
}

Although Miner et al. (2018) effectively argue that there is a need for greater efforts on the part of I-O psychologists to confront gender inequity in the STEM fields, we feel that the preoccupation with STEM may blind us to other domains where similar issues not only exist but may be even more prevalent and problematic. Specifically, we would argue that more attention needs to be

P. D. Harms, University of Alabama; Karen Landay, University of Alabama.

Correspondence concerning this article should be addressed to P. D. Harms, University of Alabama, 101 Alston Hall, Box 870225, 361 Stadium Drive, Tuscaloosa, AL 35487. E-mail: pdharms@cba.ua.edu 
paid to skilled trades, transportation-related jobs, and other so-called "dirty work."

We believe that STEM-related occupations get much of the attention among academics because of perceived shortages of individuals with STEM degrees, because such jobs are perceived to be prestigious and well-paid, and because researchers are more comfortable with occupations that they perceive as similar to their own. Consequently, there is little disagreement when the suggestion is made that we should encourage individuals, and young women in particular, to pursue such occupations. This is especially true when gender disparities in these fields are perceived to be a major driving factor of gender pay inequality. We agree that these efforts are both justified and needed, but targeting our research and development efforts on promoting STEM alone may not be enough to deal with the problem of gender inequality in the workplace or worker shortages more broadly. We therefore raise two questions regarding STEM, gender inequality, and workforce needs.

First, the question of whether there really is a shortage of individuals who are STEM-qualified needs to be addressed. The answer is a definite maybe. Not all STEM jobs are created equal. The Bureau of Labor Statistics (BLS, 2015) has provided evidence showing that, although there are worker shortages in certain STEM disciplines, there also exists a substantial oversupply of individuals with such degrees. Specifically, occupations such as computer programmers are in high demand. At the same time, for many academic professions and for industries such as chemistry, there is an excess of potential workers. For areas such as the biological and physical Industrial and Organizational Psychology sciences, mathematics, and agricultural science, the employment rates and pay are not substantially different than that of non-STEM majors. So, although there is a need for more graduates in some STEM disciplines, the prescription that more STEM graduates are needed and that people in those fields are better off can be somewhat misleading. We would argue that more precision is required for developmental or training programs to be effective. That is, they must match the demands of the job market.

The second, but often unasked, question is, where do we really need workers? According to ManpowerGroup's (2016) annual survey of talent shortage, the category of occupations that was most in demand from 2010 to 2016 is skilled trades, which includes jobs such as plumbers, carpenters, and electricians. Drivers have also placed in the top 10 every year since 2010. Although these occupations lack the prestige of STEM jobs, they can often pay substantially more than average salaries. However, women are typically much more poorly represented in these professions than they are in the STEM fields. The BLS (2017) reports that women make up only 16.5\% 
of individuals working in transportation-related jobs and even lower rates in high- demand skilled trades such as welding (4.1\%), pipefitters/plumbing (1.4\%), carpentry (2.1\%), and masonry (0.5\%). That said, the BLS (2016) also notes that pay inequality is a major problem in these sectors as well. For example, although the "most equal" category of occupations in terms of gender pay equality is construction and extraction (where women typically make $91.3 \%$ as much), other in-demand blue-collar occupations such as transportation are much less equal (76.8\%). Consequently, these occupations are potentially an even greater driver of overall gender disparities in the workplace than STEM jobs, because they are characterized by both larger gender differences in participation and, often, larger differentials in terms of pay.

That said, this by no means negates any of the points raised in the target article concerning the causes of such gender disparities or the potential solutions. There is no reason to believe that improving workplace climates, providing mentoring opportunities, educating employers and hiring managers about implicit biases, and enhancing job design would be any less effective at reducing gender inequality in blue-collar work settings. Promisingly, such efforts are already being initiated in many companies in this sector. Our goal in this commentary is simply to raise the point that we cannot fully tackle these issues if we continue to ignore substantial segments of the workforce. We agree that efforts to promote equality in both pay and participation rates is greatly needed, but we implore our fellow I-O psychology scholars and practitioners not to ignore the so-called "dirty jobs." Reviews of sampling in the organizational sciences suggest that this is all too often the case (e.g., Scandura \& Williams, 2000), and a cursory search of journals such as Journal of Applied Psychology and Personnel Psychology reveals that the last time such occupations were of serious interest to scholars was in the 1960s. Other authors have sounded the alarm of neglecting these occupations in terms of the consequences for research (Bergman \& Jean, 2016), but the issues raised by Miner et al. (2018) serve to highlight the social and practical consequences of this neglect.

Sometimes we need to be reminded that not all jobs require a university education. And there should be no stigma attached to pursuing and enjoying blue-collar work. The argument has been made that STEM as a category of jobs is too limiting and elitist in nature, and STEMS (with Skilled trades and farming being the second "S") might be preferable if we are to address the actual workforce needs of the economy and avoid excluding those who are not well-suited for or interested in a higher-education degree (engineering.com, 2015). In our view, a more inclusive approach will allow us to tailor interventions and training to the needs and desires of the participants, is therefore more likely to be successful, and better addresses the needs of the 
workforce in the future. Consequently, if we, as a discipline, are to commit ourselves to addressing the issues surrounding gender pay equity and workforce shortfalls, we need to go beyond STEM.

\section{References}

Bergman, M., \& Jean, V. (2016). Where have all the "workers" gone? A critical analysis of the underprepresentativeness of our samples relative to the labor market in the industrial-organizational psychology literature. Industrial and Organizational Psychology, 9, 84-113.

Bureau of Labor Statistics. (2015). STEM crisis or STEM surplus? Yes and yes. Monthly Labor Review. Retrieved from https://www.bls.gov/opub/mlr/2015/article/ stem-crisis-or-stem-surplus-yes-and-yes.htm.

Bureau of Labor Statistics. (2016). Women's earnings 83 percent of men's, but vary by occupation. TED: The Economics Daily. Retrieved from https://www.bls.gov/opub/ted/2016/ womens-earnings-83-percent-of-mens-but-vary-by-occupation.htm

Bureau of Labor Statistics. (2017). Employed persons by detailed occupation, sex, race, and Hispanic or Latino ethnicity. Labor Force Statistics from the Current Population Survey. Retrieved from https://www.bls.gov/cps/cpsaat11.htm

Engineering.com. (2015). Mike Rowe asks who took skilled trades out of STEM education. Retrieved from https://www.engineering.com/Blogs/tabid/3207/ArticleID/9752.

ManpowerGroup. (2016). The 10 hardest jobs to fill. Retrieved from http://www.manpowergroup.us/ campaigns/talent-shortage/.

Miner, K, N., Walker, J. M., Bergman, M. E., Jean, V. A., Carter-Sowell, A., January, S. C., \& Kaunas, C. (2017). From "her" problem to "our" problem: Using an Individual lens versus a social structural lens to understand gender inequity in STEM. Industrial and Organizational Psychology: Perspectives on Science and Practice, 11(2), 267-290.

Scandura, T., \& Williams, E. (2000). Research methodology in management: Current practices, trends, and implications for future research. Academy of Management Journal, 43, 1248-1264.

\section{STEM-ming the Tide: A Different Approach to Shaping Diverse Participation in STEM Careers}

Valerie N. Streets, James N. Kurtessis, Lindsay Northon, and Alex Alonso Society for Human Resource Management

Miner et al. (2018) have steered the trajectory of gender and STEM research in a new direction.

However, while a shift in conceptualizing women's STEM participation is needed, the distinction between individual and social-structural lenses may not be the best place to focus our efforts. Although the current empha-

Valerie N. Streets, Society for Human Resource Management; James N. Kurtessis, Society for Human Resource Management; Lindsay Northon, Society for Human Resource Management; Alex Alonso, Society for Human Resource Management.

Correspondence concerning this article should be addressed to Valerie N. Streets, Society for Human Resource Management, 1800 Duke St., Alexandria, VA 22314. E-mail: valerie.streets@shrm.org 